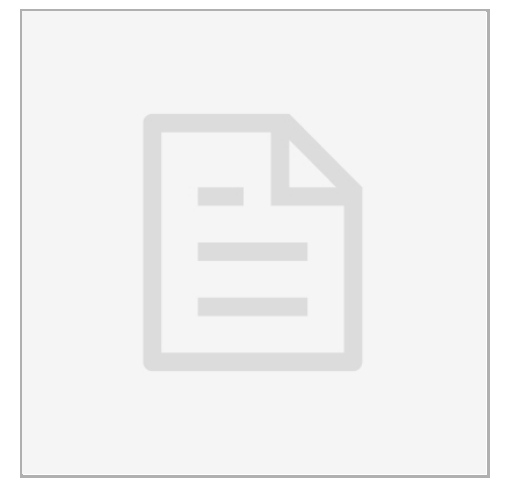

APR 25, 2018

open Әaccess

DOI:

dx.doi.org/10.17504/protocol s.io.prydm $7 w$

Protocol Citation: Kwame Agyemang Adusei, Alex K Owusu-Ofori 2018. PROTOCOLS FOR PREPARATION OF BLOOD SMEARS, REPORTING OF MALARIA PARASTTES, PROCESSING OF BLOOD SAMPLES USING MALARIA RDT (HRP-2), BLOOD GROUPING AND DESIGN OF QUESTIONNAIRE. protocols. io

https://dx.doi.org/10.17504/p rotocols. io. prydm $7 \mathrm{w}$

License: This is an open access protocol distributed under the terms of the Creative Commons Attribution License, which permits unrestricted use, distribution, and reproduction in any medium, provided the original author and source are credited

Protocol status: Working We use this protocol and it's working

Created: Apr 25, 2018

Last Modified: Apr 25, 2018

\section{(3) PROTOCOLS FOR PREPARATION OF BLOOD SMEARS, REPORTING OF MALARIA PARASITES, PROCESSING OF BLOOD SAMPLES USING MALARIA RDT (HRP-2), BLOOD GROUPING AND DESIGN OF QUESTIONNAIRE}

\author{
Kwame Agyemang Adusei ${ }^{1}$, Alex K Owusu-Ofori ${ }^{2}$ \\ ${ }^{1}$ Department of Medical Laboratory Service, School of Allied Health \\ Sciences, Kwame Nkrumah University of Science and Technology ,Kumasi, \\ Ghana .Tel: +233 501365180, Email: kwameagadusei@gmail.com; \\ ${ }^{2}$ Department of Clinical Microbiology, School of Medical Sciences, Kwame \\ Nkrumah University of Science and Technology, Kumasi, Ghana. Tel: +233 \\ 209149370, Email: owusu_ofori@hotmail.com
}<smiles>C1CCCCCC1</smiles>

Kwame Adusei

ABSTRACT

LABORATORY PROTOCOLS FOR PREPARATION OF BLOOD SMEARS, REPORTING OF MALARIA PARASITES, PROCESSING OF BLOOD SAMPLES USING MALARIA RDT (HRP-2), BLOOD GROUPING AND DESIGN OF QUESTIONNAIRE (PREVALENCE OF PLASMODIUM PARASITAEMIA IN BLOOD DONORS AND A SURVEY OF THE KNOWLEDGE AND PRACTICES OF TRANSFUSION MALARIA AMONG HEALTH WORKERS IN A HOSPITAL IN KUMASI, GHANA

\section{MATERIALS}

MATERIALS

88 Monoclonal antisera $A, B$ and $D$ Contributed by users 
PROTOCOL integer ID:

11800

Keywords: Blood donors, microscopy, rapid diagnostic test (HRP-2), blood films, blood groups

\section{PREPARATION OF THICK SMEAR FOR MICROSCOPY}

1 A drop of well mixed blood (6ul) was placed on a clean grease free slide using a pipette.

2 An applicator was used to spread the drop of blood in a circular way to ensure the spread of blood with moderate thickness, covering evenly an area about $1 \mathrm{~cm}$ diameters.

3 Slides were labeled with subject's code number and allowed to air-dry.

4 The smears were stained with a freshly prepared $10 \%$ Giemsa stain for 15 minutes and washed with clean distilled water.

$5 \quad$ The slides were then placed on a drying rack in a vertical position and allowed to air dry.

\section{PREPARATION OF THIN SMEAR FOR MICROSCOPY}

6 A drop of well mixed blood (2ul) was placed about $1 \mathrm{~cm}$ from the frosted end of a slide using a pipette.

7 A smooth clean edge of a second slide (spreader) was placed on the specimen slide, just in front 
of the blood drop.

8 The spreader slide was held at $30^{\circ}$ angle and was drawn back against the drop of blood.

9 As the blood started to spread to the ends of the spreader, the spreader was pushed forward with a light, smooth, and quick steady motion.

10 The frosted edge was labeled with the subject's code number and the blood smear was dipped in a Coplin jar containing absolute methanol for 10 seconds and then air dried again.

11 The smear was then stained with a freshly prepared Giemsa stain solution for 30 minutes and washed with distilled water

12 The slides were then placed on a drying rack and allowed to air dry. An oil immersion was put on the prepared thick film and was examined using the $X 100$ objective lens and the thin films were first examined using the $X 40$ with an oil immersion placed to the feathery tip of the smear to check the staining, morphology and distribution of the cells and afterwards the objective lens is changed to $\mathrm{X} 100$ to examine the malaria parasites.

\section{REPORTING OF MALARIA PARASITES}

13 Number of parasites seen were counted in relation to a predetermined number of white blood cells and an average of $8000 / \mu \mathrm{l}$ was taken as standard. 200 white blood cells were counted in 100 fields. All parasite species and forms including both sexual and asexual forms were counted together.

14 NUMBEROF PARASITES/ $\mu \mathrm{L}=$ Number of parasites counted $/$ Number of white blood cells counted $\times 8000$ 
15 In the laboratory, 5ul of whole blood from the labeled EDTA tube, was taken with a pipette provided with the test kit.

16 The blood was pipetted into the round sample well of the RDT.

17 Four drops of assay diluent were placed vertically into the square assay diluent well and the results were read after 30 minutes.

18 The same procedure was performed on samples collected from blood donors and non-donors.

19 A positive results was recorded when the test and control bands appeared after 30 minutes. A negative results was also recorded when only the control band showed.

\section{BLOOD GROUPING}

20 The tile method using the forward grouping was used for determining the blood groups of blood donors and non-donors (controls).

$215 \mathrm{ul}$ of blood donors and non-donors blood samples were put in the appropriate square of the tile.

22 A drop of a known antisera was added to the sample. 
23 An applicator was used in mixing and the tile was rocked forward and backward for 3 minutes. The results were read macroscopically upon agglutination and in cases where the results were unclear, were read microscopically

\section{QUESTIONNAIRE}

24 The questionnaire was categorized into a three-part document with a socio-demographics section, knowledge section and a section on attitudes and practices. Responses to a total of 20 opened and closed complete questions were unspecified so as to obtain validated answers without fear of victimization. Health workers were given less than 24hours to fill the questionnaire and those who did not submit were followed up in person 